\title{
Charismatic Christianity and Pentecostal churches in Estonia from a historical perspective
}

$\mathrm{T}$

his article focuses on the history of Pentecostal and charismatic Christianity in Estonia from the early twentieth century to the early twenty-first century. From the 1870 s onwards a series of religious revivals in Estonia created the context for the emergence of the Pentecostal movement in the early twentieth century. Proto-Pentecostalism at the beginning of the century transformed into a fully-fledged Pentecostalism in the 1920 s with the involvement of foreign missionaries from Sweden as well as from Finland. The Finnish connection became important in the late 1960s with the emergence of a charismatic Pentecostal revival in the evangelical Christian churches, as well as amongst the Baptists in Tallinn. By the late 1970s the prayer revival had transformed into a healing ministry and this had an impact on the charismatic movement in the Soviet Union. The foreign impact on Pentecostal and charismatic movements in Estonia has also been important from the late 1980 os onwards. There has been considerable diversification of the charismatic and Pentecostal traditions in Estonia since the 1990s, and the trends have reflected general changes in charismatic Christianity. Although internally diverse the charismatic Christianity (including the Pentecostals) may well be by now the second largest Protestant tradition in Estonia.

\section{Introduction}

At the beginning of the twenty-first century the Estonian religious landscape is still dominated by Christianity. Besides the two dominant denominations, the Lutherans and the Orthodox churches, there are also a number of new charismatic and Pentecostal churches and movements present in Estonia. In 2014 there were over 570 religious associations with legal entity status. The majority of these are part of larger churches or congregational associations. However, there is also a considerable number of independent charismatic and Pentecostal congregations.

The largest Pentecostal church in Estonia is the Estonian Christian Pentecostal Church (Eesti Kristlik Nelipühi Kirik) that began its formation in 1989. However there is also the Association of Estonian Evangelical Christian Pentecostal Congregations (Eesti Evangeeliumi Kristlaste Nelipühilaste Koguduste Liit), the Association of Estonian Christian Free Churches (Eesti Kristlike Vabakoguduste Liit, which unites the Word of Life [Elu Sõna] congregations), and several independent congregations, as already mentioned. At the same time there are congregations in the Estonian Union of Evangelical Christian and Baptist Churches (Eesti Evangeeliumi Kristlaste ja Baptistide Koguduste Liit) with Pentecostal influences and/or backgrounds.

The history of Pentecostal and charismatic Christianity in Estonia is as yet largely unwritten. Much of the available knowledge on the early phases of the Pentecostal movement in Estonia relies on the memoirs of Evald Kiil (1997) who started his career as a Pentecostal preacher in the 1930s. The 1970 charismatic revival is covered by memoirs or books based on the memoirs of the participants (Uuemõis 2010, Kraeuter 2012). Toivo Pilli (2008), Riho Saard (2010) and Jaanus Plaat (2001) have also paid attention to the movements, however, often in a more general revivalist context. There are also some unpublished BA, MA and PhD theses on charismatic and Pentecostal Christianity in Estonia (Ritsbek 1996, Kroll 2006, Hermaküla 2007).

There is lack of reliable information concerning Pentecostalism and charismatic Christianity 
in Estonia. Thus for example it has been estimated that there were between 200 and 2,000 Pentecostals in Estonia in the 1930s (Teraudkalns 2001: 98). According to the 1934 population census there were 191 persons who defined themselves as Pentecostals, 459 affiliates of Free Gospel Churches, and 306 Revivalists, which amounted to less than 1 per cent of the population (Rahvastiku koostis ja korteriolud 1935: 118-21).

\section{Relevant historical background}

In the sixteenth century the Lutheran Church became the dominant Landskirche, as it is in present day Estonia. The religious diversification of Estonia started in the eighteenth century with the arrival of the Moravian Brethren missionaries from Herrnhut, Germany. The Brethren movement (vennastekogudus) was initially invited by the Baltic German gentry and clergy who were influenced by Pietism, but due to the missionary efforts of the Brethren it became popular among the native peasantry and was accompanied by ecstatic movements (Vööbus 1974: 103-46). From the early eighteenth century onwards a variety of local prophets and ecstatic movements emerged. One of the best known examples of the ecstatic movements are the heaven- or skywalkers (taevaskäijad), who were mostly young maidens who claimed to visit heaven as well as hell, and brought back messages (Plaat 2001: 42-4).

\section{The 1870 s revival}

From a more recent perspective the introduction of charismatic Christianity into Estonia can be said to have taken place at the end of the nineteenth century during the period of Russian imperial Russification. The coastal Swedes of north-western Estonia, who had become the subjects of the Russian czar as a result of the 1721 Nystad peace treaty, became concerned at the missionary activities of the Russian Orthodox Church and in 1873 the Swedish evangelization society, the Evangelical Homeland Foundation (Evangeliska Fosterlandsstiftelsen) sent missionaries to Estonia at the request of the Lutheran clergy of the coastal Swedes (Plaat 2001: 62-3; Kaups 1935: 102-5). Thure Emmanuel Thoren and Lars Österblom were missionaries and schoolteachers who triggered revivals among coastal Swedes in Noarootsi/Nuckö (1874) and the island of Vormsi/
Örmso (1876). The coastal Swedes have lived side by side with ethnic Estonians for centuries along the west coast of Estonia and it was from there that the revival spread among local Estonians. On the island of Ormsö the revivalists split away from the Lutheran Church in 1880. By that time the revival had spread to the rest of western Estonia and in 1879 it became known as the Ridala (or West Coast) revival, referring to its central hub (Plaat 2001: 66-7; Busch 1928).

Among local peasants the revival took different forms including more charismatic features such as jumping, clapping hands, dancing, shaking, and speaking in tongues. The revivalist movement became known as the free-churchers (priilased) or the revivalist free churches.

When the German Baptist pastor Adam Schiewe from St Petersburg arrived in Estonia in 1884 the revival was in full swing. In February 1884 Schiewe conducted the first baptisms of faith in Estonia (Wardin 2013). In subsequent years some of the revivalist free churches joined Baptists who were permitted to operate in the Russian Empire, while some of the revivalist free churches remained as independent, close-knit communities. The Baptists became one of the fastest-growing religious denominations in the ensuing decades.

The end of the nineteenth century and the first decade of the twentieth century were years of rapid urbanization and industrialization and this was also a time when many Christian traditions new to Estonia arrived. In 1897 the Seventh-day Adventists arrived, followed by Methodists in 1905 and an emotionallycharged local revival also took place in 1905, started by a young revivalist preacher, the Jewish-born Lutheran convert Johannes Rubanovitsch (Betz and Lohmeyer nd). The 1905 Pietistic revival movement became known as the Evangelical Christians (evangeeliumi kristlased) (Pilli 2008: 3).

\section{The Pentecostal movement at the beginning of the twentieth century}

The exact birthdate of the Pentecostal movement in Estonia is rather hard to establish. Many of the features which are often characteristic of the Pentecostal movement (such as speaking in tongues, for example) had already been introduced into Estonian religious life before the end of the nineteenth century, as a consequence of various revivals. The Pentecostal movement has been viewed as a continuation of the holi- 
ness movement which had arrived in Estonia in the 1890s (Pilli 2007: 233).

The earliest contacts with proto-Pentecostal movements date back to the early 190os when Baroness Margarethe von Brasch, having been filled with the Spirit at an evangelical service in Germany had begun to organize worship services at her home in Estonia. The British missionary Eleanor Patrick, who became Pentecostal in 1908 and had a role in the Pentecostal mission in Russia, also visited Estonia between 1909 and 1912 (Anderson 2014: 108; Mozer and Bornovolokov 2011: 261).

The arrival of Pentecostal movement to Estonia has been dated back to 1907 when a Finn, Pekka Hakkarainen, who became later important in the Pentecostal movement in south-eastern Finland, began his preaching career in Narva Baptist services (Kiil 1997: 14-15; Schmidt 1935: 101). In 1909 Pekka Hakkarainen, along with his 22 followers, founded an independent church called the Narva Evangelical Christian Congregation (Narva Evangeeliumi Kristlaste Kogudus), which is considered to be the first Pentecostal congregation in Estonia (Kiil 1997: 14-15). His work in Narva was continued by Aleksander Summanen who in 1928 became an official missionary of the Finnish Pentecostal mission organization, the Finnish Free Foreign Mission (Suomen Vapaa Ulkolähetys; Schmidt 1935: 208, Kärkkäinen 2003: 125).

Narva and its surrounding areas in north-eastern Estonia have also been important in the history of the Finnish Pentecostal movement. In 1898 a revival that became known as Narva revival, or narvalaisuus ('Narvaness') emerged among the Finnish-origin Laestadian movement in Narva, northeastern Estonia, Ingria and south-western Finland (Kärkkäinen 2003: 105; Talonen 1988: 22-3). This branch of the Laestadian movement in Finland invited the founding figure of the European Pentecostal movement, the Norwegian Thomas Ball Barratt (1862-1940) to visit Finland in 1911 (Alvarsson 2011: 22-9). Barratt's visit to St Petersburg in the same year had an impact on the Pentecostal revival among Finns living in the capital of the Russian Empire (Schmidt 1935: 205).

\section{The Pentecostal movement in independent Estonia}

In 1918 Estonia was declared an independent liberal democratic republic. The Constitution of 1920 stipulated freedom of religion and indicated that there was no state religion. The governmental attitude to religion was rather indifferent. In 1922 the first Swedish missionary came to Estonia with the intention of learning the Russian language, as in the 1920 Russia was seen as a potential missionary country. Yngve Valdemar Ölvingsson (also known as Voldemar Ellingsson) settled in north-west Estonia amidst the Swedish settlements along the coast. He had been affiliated with the Methodist Church and had become associated with the Swedish Pentecostal movement. His preaching became popular among revivalist circles. In 1924 Ölvingsson established his first Pentecostal church in Estonia, called the Free Gospel Congregation, in Riguldi (Plaat 2003: 151). In 1925 Ölvingsson moved to Tallinn where he became an organizer amongst the Pentecostal groups, founding the Elim Pentecostal Church in Tallinn in 1926 (Kiil 1997: 20-3; Anderson 2014: 108; Teraudkalns 2001: 98; Schmidt 1935: 207-8). In the years following the Elim Church established local charters in a variety of places in Estonia (Plaat 2003: 151). From 1922 to 1926 several Pentecostal missionaries came from Sweden with affiliations to the Pentecostal movement in Stockholm.

In1934 Estonian legislation concerning religious associations changed and the independent Pentecostal churches had to either organize themselves into a larger congregational union or merge with an already-existing religious union. Most of the Pentecostal churches merged with the Union of Estonian Evangelical Christian Free Churches (Eesti Evangeeliumi Kristlaste Vabakoguduste Liit), but still maintaining their particular spiritualities (Pilli 2007: 235).

\section{The Soviet period: merging traditions}

The Soviet occupation which took place after the Second World War brought more changes to Estonian religious life. In 1945 the Estonian Baptists, Revivalist Free Churches and Evangelical Christians with Pentecostals were merged into the Union of Evangelical Christian Baptists in the USSR. The congregations of this Union in Soviet Estonia were very diverse in their spiritualities. The most extreme example of the outcome of the forced merger was the creation of a congregation in Oleviste, or St Olaf's Church, in Tallinn where seven different congregations were united into one. The congregation was 


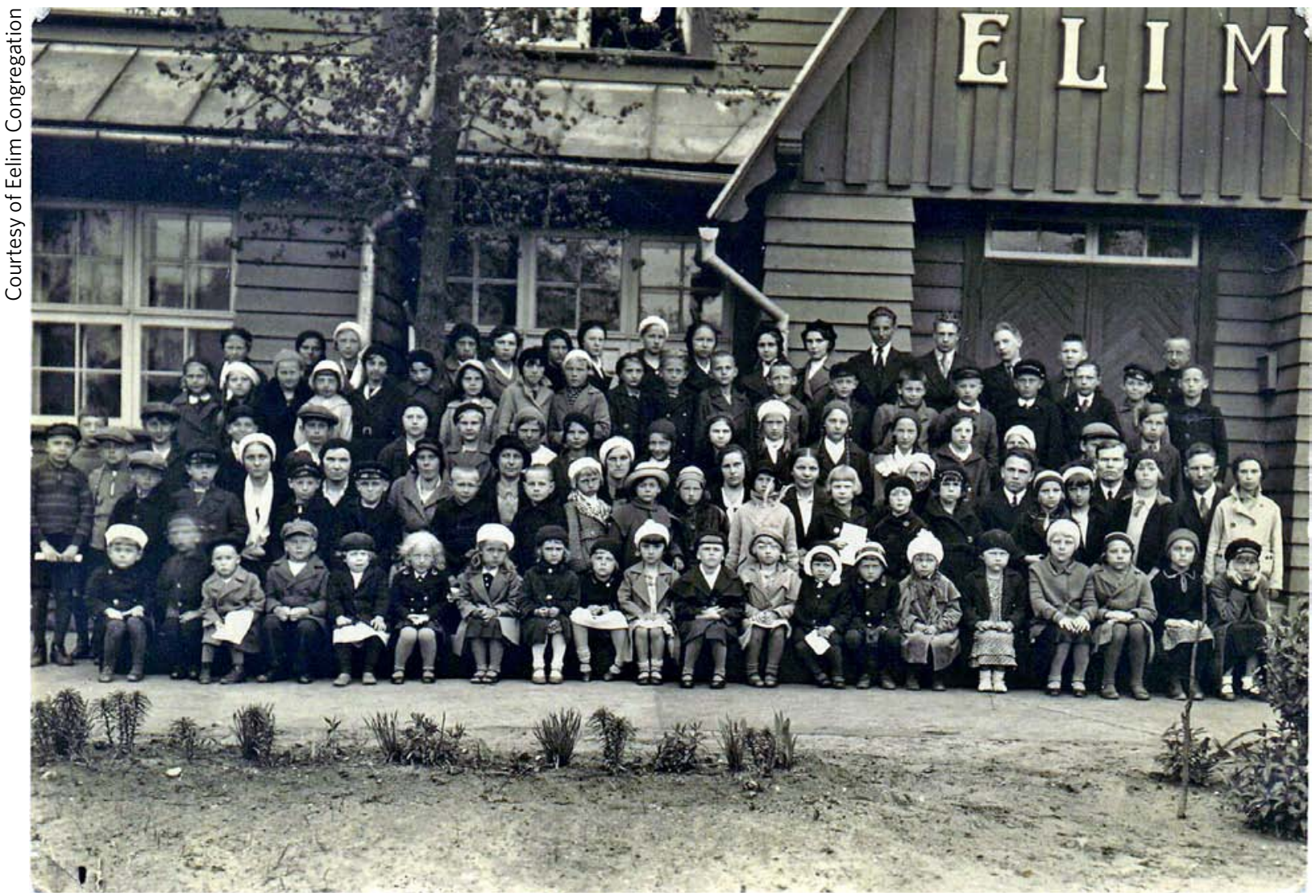

The Eelim Congregation's Sunday School in 1933.

established on 17 September 1950 on the basis of three Evangelical Christian, three Baptist, one Pentecostal, and one revivalist free $\operatorname{church}^{1}$ (Pilli 2008: 38-42). The blending of the different spiritualties resulted in Oleviste becoming the centre of a charismatic revival that started in the beginning of the 1970 s and lasted for almost a decade until the Soviet authorities intervened (Saard 2010: 29-32; Kraeuter 2012: 83-97).

\section{Charismatic revivals during the Soviet period}

On 7 June 1965 the first regular ferry link between Helsinki and Tallinn was established. This connection had an impact on the religious life in the Soviet Estonia, as contacts with the Western world consequently became unofficially established, or reestablished at an individual level. The ferry link became

1 Evangeeliumi Kristlaste Vabakogudus, Karmeli Evangeeliumi Kristlaste Vabakogudus, Siioni Evangeeliumi Kristlaste Vabakogudus, Allika Baptistikogudus, Saaroni Baptistikogudus, Iru Betaania Baptisti Kogudus, Eelimi Nelipühikogudus, Priikogudus. an important vehicle for the transmission of new influences from the charismatic movement (Pilli 2008: 72). Pentecostal and charismatic theological perspectives were introduced through the books of Tommy Lee Osborn and Derek Prince, which were smuggled into Soviet Estonia. In the 1970s the Jesus movement reached Estonian Christian circles. The Jesus movement was reflected in the religious youth awakening which centred around a gospel-rock band named 'Sela' which had been formed in 1968 in the Methodist Church of Tallinn. In 1978 the gospel band 'Living Sound' from Oral Roberts University visited Estonia and performed in the Oleviste Church as well as in the Methodist Church in Tallinn. Before leaving Soviet Estonia Living Sound gave its technical equipment to the band Sela, which by the 1970s had also become popular outside of religious and hippie circles (Saard 2010: 12-13). The charismatic circles around Sela had contacts with outreach ministries in the West and were involved in the emerging Jesus movement in Leningrad, Moscow, Kiev and Riga, being the first gospel rock band in the Soviet Union (Kärner 27.5.2006; Pilli 2008: 93). Emerging charis- 
matic Christianity, especially in its Jesus movement form, became part of the alternative sub-culture of the Soviet Union.

In 1966 the first Pentecostals from Finland, who came to Soviet Estonia as tourists, visited Oleviste Church (Pilli 2008: 72). Finnish Pentecostals and charismatic free churches also smuggled charismatic literature into Estonia, and in the 1970s Oral Roberts and Kenneth E. Hagin were among the authors whose books were translated into Estonian and distributed as samizdat publications in charismatic circles (Pilli 2008: 92; Saard 2010: 19-24).

In the spring of 1968 a prayer awakening took place among the members of the Oleviste Church. Two central figures in this prayer awakening were the brothers Rein and Haljand Uuemõis who had a background in the evangelical Christian movement, and whose house became the place for prayer meetings in which guests from Finland also participated. In 1968 the Oleviste Church evangelization effort took the form of choir evenings in which traditional spiritual songs were performed and an outreach speech was also included. Gradually the evenings of spiritual music performed by the Effataa Choir, as it was known from 1975, began targeting the younger generation with gospel rock and in 1976 the choir evenings moved from the side chapel to the main hall of the medieval Oleviste Church (Kõlar 2012: 144). At the same time speaking in tongues became a controversial issue among the evangelical Christian and Baptist church leaders (Pilli 2008: 92). The connection with Finnish Pentecostal and free churches and the influence of the charismatic ministry of Niilo YliVainio also played a role in the revival which began at Christmas 1977 with a healing ministry led by Rein Uuemõis (Uuemõis 2010: 43; Pilli 2008: 92).

Healing ministry in the Oleviste Church was carried out both in Estonian and in Russian, and it especially attracted underground Pentecostals from elsewhere in the Soviet Union. In the following four years this revival brought thousands of people from other parts of the Soviet Union to the healing services (Kraeuter 2012). The Tallinn revival, or Effata revival, also had an impact on Pentecostal and charismatic Christianity in the rest of Soviet Union.

The Soviet authorities closed down the charismatic healing ministry in the Oleviste Church in 1981 (Saard 2010: 29-32; Kraeuter 2012: 83-94).

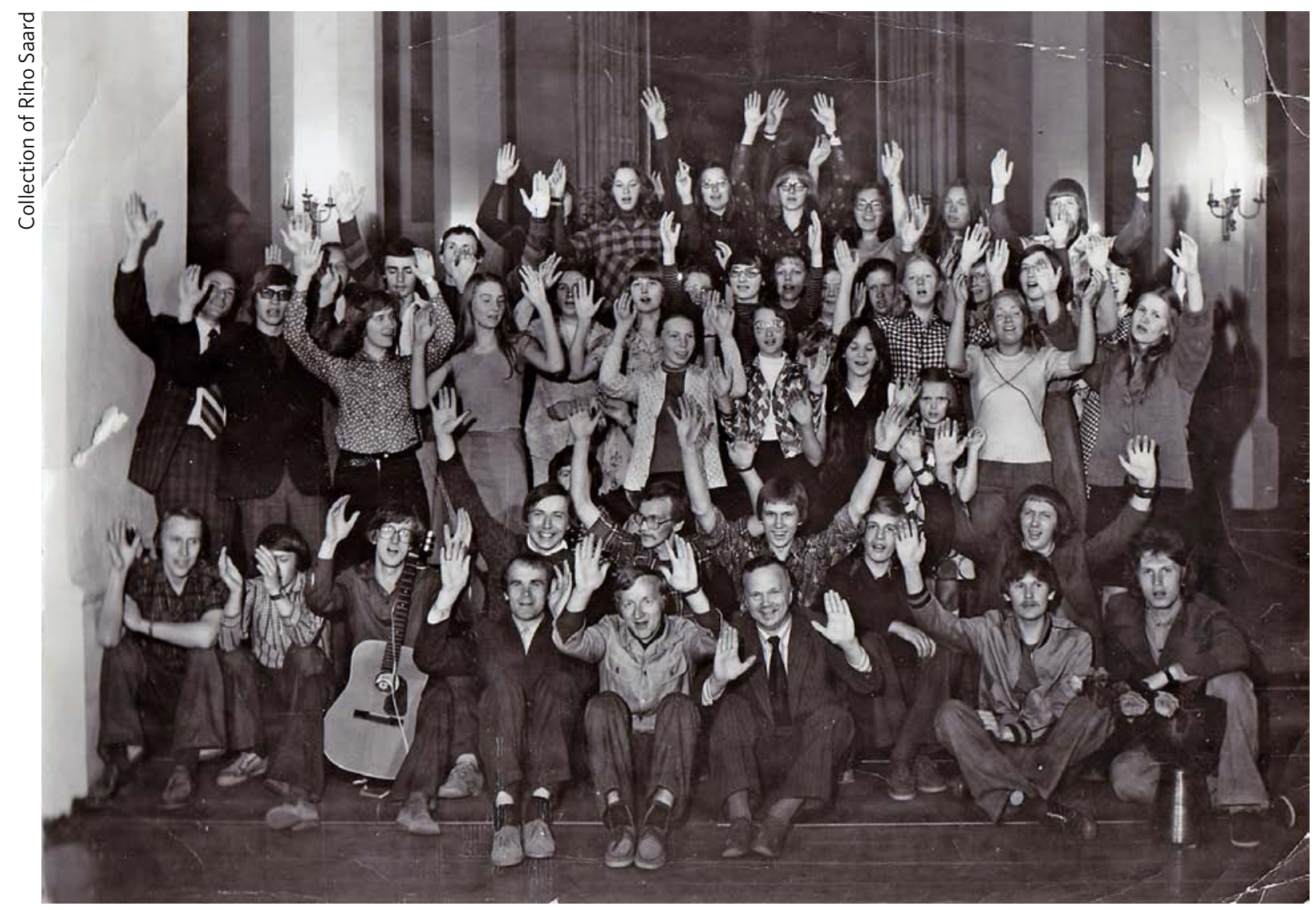

The Effataa Choir at St Oleviste Church in 1979. 


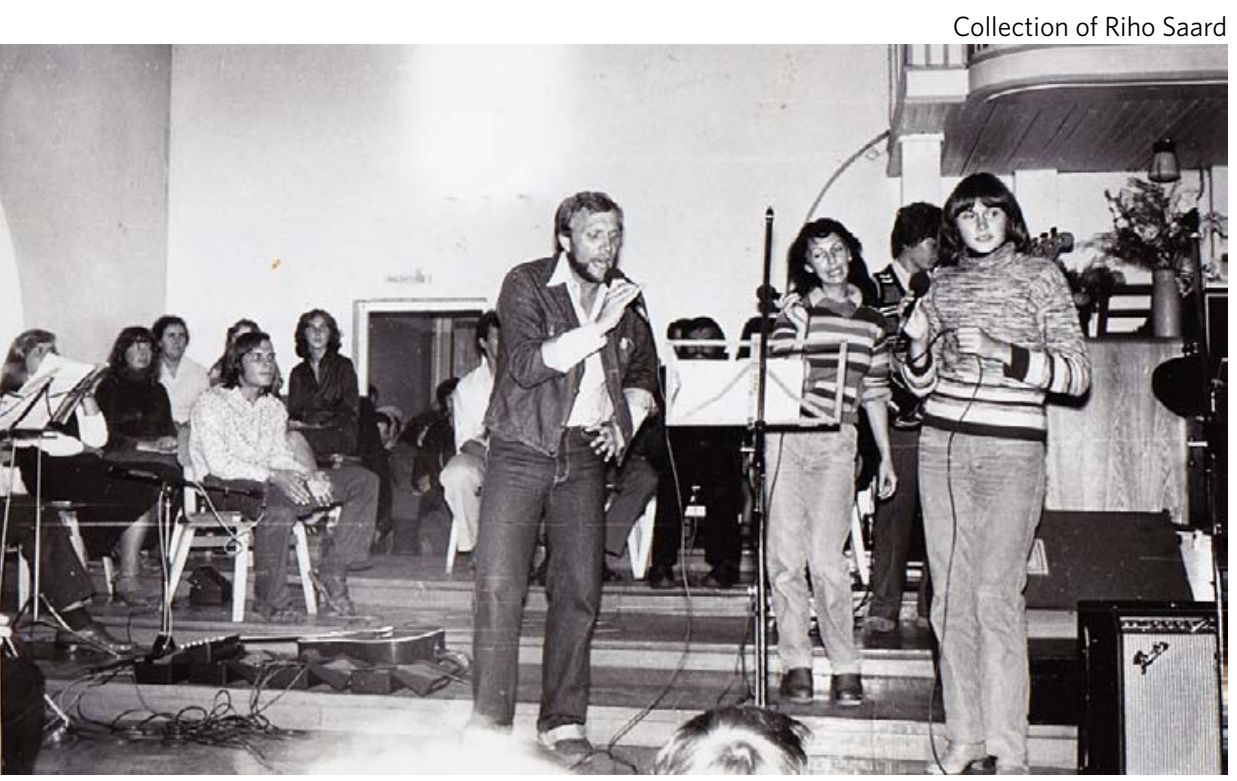

Rein Mets, Marju Kuut and Kadri Hunt at the Methodist Church prayer service in Tallinn, 1980.

However, both the Oleviste Church and Methodist Church in Tallinn remained important for the subsequent charismatic youth revival that began in 1986 after the Methodist Church in Tallinn had excommunicated two active congregation members, Rein Mets and Hubert Jakobs. Rein Mets was 'born again’ in the Oleviste Baptist church in the late 1970s, but due to disagreements with the congregation's administration had left it. Hubert Jakobs had been an active translator of charismatic teachings but in 1986 he left Oleviste due to doctrinal differences. In 1986 Mets started engaging in youth work in the Methodist church with his new co-worker Hubert Jakobs (Hermaküla 2007: 14-16). The works of Kenneth E. Hagin, translated by Jakobs, became the main source of inspiration for the new charismatic revival.

\section{The Word of Life revival}

Rein Mets and Hubert Jakobs were expelled from the Baptist and Methodist churches on grounds of theological differences. A prayer meeting of the youth groups led by Mets and Jakobs had become excessively ecstatic. Because of these developments the leadership of the Methodist church removed Mets and Jakobs from the youth work, and as the confrontation continued to grow Mets and Jakobs were excommunicated from the Methodist Church in December 1986 (Hermaküla 2007: 18). Rein Mets and Hubert Jakobs and their followers joined a Bible study and prayer group led by Hubert's brother
Raimond Jakobs. In 1987 this prayer group became known as the Word of Life (Elu Sõna) (Saard 2010: 58). The name was given spontaneously during a prayer and Hubert Jakobs has denied any connection to the name of the Swedish movement called 'Livets Ord' (Hermaküla 2007: 18).

The Word of Life was radical both in its approach to religion as well as to Soviet society. One fundamental feature of the Word of Life was Kenneth E. Hagin's teaching on 'spiritual warfare. Mets and Jakobs attracted mostly people in their late teens or early twenties. Speaking in tongues and casting out demons characterized the Word of Life's prayer meetings. Due to the young age of the followers and unusual charismatic spirituality some parents expressed their concerns to the Soviet authorities, who on their own account were also concerned about the political message of the movement.

In October 1987 Jakobs and Mets made a religious-political declaration under the title Harta ' 87 ('Charter ' 87 '), which was sent to the President of the United States at the time, Ronald Reagan; the Secretary General of the Communist Party of the USSR Mikhail Gorbachev and the Chairman of the Presidium of the Supreme Soviet of Soviet Estonia, Arnold Rüütel. In this address Mets and Jakobs renounced their Soviet citizenship and called for an 'exodus' from the Soviet Union, 'as the godly leave the Empire of Evil'. Ultimately 404 persons signed this petition. There were similar religious-political statements directed against the Soviet Union from the Word of Life in 1987, along with a missionary visit to Vilnius, Lithuania. As Hubert Jakobs has explained he understood Kenneth E. Hagin's idea of the believer's authority to apply not only to the spiritual, but also to the political sphere of life (Jakobs 2002). The Word of Life was also the first to use the Estonian national colours in public (Laar et al. 1996: 201). At the same time they were the target of critical articles in the local press as well as on television, and a criminal investigation into Mets and Jakobs was started by the Soviet authorities.

In February 1988 Mets and Jakobs, along with their families, were deported from the Soviet Union to Sweden. From there on the Word of Life in Estonia 
became less politically involved (Rohtmets and Ringvee 2013). Eventually the Word of Life revival split into different charismatic churches. The Soviet authorities registered the first Word of Life congregation in 1989. Albert Türnpu became the new charismatic leader of the Word of Life movement, now with its headquarters in Tartu. Mart Metsala in Tallinn formed the Way of Light Free Church (Valguse Tee Vabakogudus). In the 1990s the Word of Life was the flagship of the charismatic movement in Estonia. In 1994 the Word of Life congregations founded their own congregational association, the Estonian Association of Christian Free Churches (Eesti Vabakoguduste Liit). From 1994 to 2001 the Word of Life published its weekly Elu Sõna Leht ('Word of Life Newspaper'). In 1996 the Word of Life congregation in Tartu established a private primary school. The school is still operating and has permanent accreditation from the Ministry of Education.

In the context of late 1980 os charismatic scene in Estonia the Estonian Word of Life (Elu Sõna) had by 1987 established contacts with Livets Ord (the Word of Life) Church in Sweden, founded by Ulf Ekman (Hermaküla 2007: 22). Among these contacts Carl Gustaf Severin, a graduate from Rhema Training Centre, became an important figure. In the early 1990 some charismatic ministries saw Estonia as a bridgehead for the mission to Russia. In the late 1980 os Livets Ord had started its mission plans for Russia (Aronson 2011). In 1990 the Estonian Word of Life established, in cooperation with its Swedish counterpart, a non-accredited Bible-school for the students from the Soviet Union in Tartu. However, since the early 2000 s the role of the Word of Life in Estonian religious life has been diminishing as the charismatic leader of the movement, Albert Türnpu moved from Estonia to Israel.

\section{Charismatic, Pentecostal and convergence movements since the 1990s}

The Pentecostal movement in Estonia revived in the 1990s. In 1988 the Soviet Union celebrated a thousand years of the Christianization of Russia. Although these celebrations focused on the Orthodox Church, the Pentecostals from Latvia and Russia managed to organize a large evangelization event in Tallinn. On 24 July 1988 the Tallinn city concert hall was full, which means that approximately seven thousand people attended the event (Pilli 2008: 123-4).
One of the first attempts to organize the Pentecostals in Estonia was made in 1989 by the Pentecostal pastor Heino Veensalu who founded the Estonian Evangelical Christian Pentecostal Church (Eesti Evangeeliumi Kristlaste Nelipühilaste Kirik). In 1991 the name of the church was shortened to the Estonian Pentecostal Church (Eesti Nelipühi Kirik). After the death of Rev. Veensalu in 1992 the church was dissolved (Rohtmets 2009: 275-6).

In 1991 Estonia reestablished itself as an independent republic. The general liberation was also seen in the influx of new charismatic and Pentecostal churches, missions and ministries, and new forms of Christian religion. As in the 1920 s the new charismatic and Pentecostal movements became a challenge to the traditional free churches once again (Pilli 2008: 123-6; Laks 1966: 97-100) In the 200os the Estonian Christian Pentecostal Church (Eesti Kristlik Nelipühi Kirik) became to define the mainline Pentecostal churches. In 1989 three Estonian Pentecostal ministers, Allan Laur and Märt Vähi from Canada and Harry Leesment from Australia, visited Estonia, and started a neo-Pentecostal ministry in Estonia. In the following year they had their first summer Bible school; the Estonian Christian Seminar. In 1991 Laur, Vähi and Leesment founded the Estonian Christian Church (Eesti Kristlik Kirik) after consultations with the leaders of other free churches already operating in Estonia.

In 1994 the Estonian Christian Church, under pressure from other churches as well as from the state officials, changed its name to the Estonian Christian Pentecostal Church (ECPC). In 1995 the ECPC became an observer member of the ecumenical Estonian Council of Churches (acquiring full membership in 1997), indicating acceptance from the mainline Christian churches in Estonia. The ECPC exemplified the proactive approach in spreading the message. The ECPC was involved in establishing the Christian radio station and media channel Raadio7 in cooperation with the International Broadcast Radio Association in the early 1990 os (Raadio7 website). The ECPC has also been active in social rehabilitation, and in 2000 Bishop Märt Vähi established the Village of Hope which now has two centres for the programmes (Village of Hope webpage). The ECPC is the largest Pentecostal denomination in Estonia, with thirty congregations.

In addition to the aforementioned charismatic and Pentecostal churches there is also a number of 
smaller congregations or churches (including full gospel' churches) and their associations (the Union of Estonian Evangelical and Free Churches, the Union of Estonian Christian Congregations, the Estonian Association of Evangelical Christian Pentecostals). The charismatic subculture comprising various small congregations had already become part of the general religious field in the 1990s. One example of the fluidity of the Christian charismatic scene is the Vineyard Church in Estonia. The Vineyard movement was introduced to Estonia in 1999 by Miguel and Mai Zayas who had moved to Estonia from the USA. At first they became involved in charismatic circles and in 2003 they established their own congregation. From 2009 the congregation has operated under the name of the Vineyard Congregation of the Estonian Pentecostal Christian Church (Ringvee 2012a).

The convergence movement was brought to Estonia by former Methodist pastor Heigo Ritsbek, following his studies in the United States. The Estonian Charismatic Episcopalian Church (Eesti Karismaatiline Episkopaalkirik) was introduced to Estonia in 1995, and is a fellowship church of the International Communion of the Charismatic Episcopal Church. In 2006 the Charismatic Episcopalian Church became a full member of the ecumenical Estonian Council of Churches (Ringvee 2012b). However, in $2012 \mathrm{H}$. Ritsbek left the Charismatic Episcopalian Church and became the head of the Anglo-Catholic Church in Estonia of the Holy Catholic Church International (Eesti Anglokatoliku Kirik). In this process an independent charismatic congregation, the Estonian Charismatic Neo-Catholic Congregation (Eesti Karismaatiline Neokatoliku Kogudus) was established. In 2013 the Charismatic Neo-Catholic Congregation changed its name to the Congregation of the Catholic Charismatic Church in the Land of St Mary (Karimaatilise Katoliku Kiriku Maarjamaa Kogudus). All of these have tiny membership numbers, even on an Estonian scale. According to the 2011 population and housing census there were 79 affiliates of the Charismatic Episcopalian Church and 99 affiliates of the Charismatic Fellowship Church older than 15 years of age (Housing and Population Census Database 2011).

Characteristic of the Estonian charismatic field has been the importance of individuals who cross the denominational borders. One of them is the current Patriarch Archbishop and Rabbi of the Estonian
Charismatic Fellowship Church (Eesti Karismaatiline Osaduskirik), Georg Benjamin Lillemäe. Georg Lillemäe was ordained as a minister of the Estonian Evangelical Lutheran Church from 1975 until 1993. During the religious revival of the late 1980 os and early 1990s, Lillemäe became extensively involved in the new charismatic revival. In 1993 Lillemäe established his first independent charismatic church in Põlva, which became part of the Estonian Christian Church. In 1994 the congregation became known as the New Life congregation, and in the following few years Lillemäe was involved in founding over twenty New Life congregations around Estonia. In 1996 when the former Methodist pastor Heigo Ritsbek brought the Episcopalian Charismatic Church to Estonia Georg Lillemäe became associated with this new church. In 2000 Lillemäe established a new church, called the Estonian Charismatic Fellowship Church, which combines elements from different Christian traditions and even from Judaism (Eesmaa 2012). The Charismatic Fellowship Church could also said to be part of the convergence movement. In 2014 the church had five congregations, and the main hub of the Charismatic Fellowship Church is still located in Põlva. However, Lillemäe is also actively involved in missionary work in Ghana.

\section{Nigerian charismatic churches}

A new feature in the Estonian charismatic field in recent years has been the emergence of Nigerian charismatic Christianity. In 2013 three Nigerian students studying at Tallinn Technical University established a regular, not-for-profit association called the Estonian Chapel of the Redeemed Christian Church of God (Lunastatud Kristlaste Jumala Armu Kiriku Eesti Kabel). Soon afterwards, in April 2014 a Nigerian preacher, Uche Alexander Anyanwu, along with eleven other founding members, registered the statute of the Estonian Congregation of Christ Embassy (Kristuse Saatkonna Eesti Kogudus). The Estonian congregation is affiliated with Nigerian pastor Chris Oyakhilome and his Believers' LoveWorld Inc./ Christ Embassy Church. The reasons for the arrival of Nigerian charismatic churches to Estonia are hard to detect, but may be related to the growing number of Nigerian students in Estonian universities and connected with the general expansion of Nigerian charismatic ministries in Europe. 


\section{Conclusion}

One of the general features of the Pentecostal and charismatic movements has been their connection to a wider revivalist context, including the international context. Many of the features common to the contemporary Pentecostal and charismatic religiosity and its expressions have been present in Estonia since the arrival of the Moravian movement in the first half of the eighteenth century. The Moravian movement with its local variants laid the general spiritual foundation for the revivals which followed. The West Coast revival of the 1870 s emerged among the coastal Swedes and was triggered by the religious activity of Swedish missionaries. The religious revival in Tallinn and north-eastern Estonia were influenced by the religious milieu of St Petersburg, the capital of the Russian Empire, which contains a considerable Estonian community. The historical Estonian eastern border town of Narva, which became a major industrial town in the nineteenth century was just one hundred and fifty kilometres west of the capital. The Narva Revival of the Laestaedian movement in Estonia, Ingria, St Petersburg and southern Finland finally became realized in relation to the visits of one of the leading Pentecostal leaders in Europe, T. B. Barratt in 1911 as well as the Finnish Pentecostal movement. However, Pentecostalism proper arrived in Estonia in 1922 from Sweden, fitting in to the already present revivalist atmosphere of the coastal Swedes and Estonian west coast. At the same time Finnish Pentecostals supported the Estonian mission in north-eastern Estonia. After twenty-five years of non-communication a ferry link between Tallinn and Helsinki became a new pipeline along which charismatic and Pentecostal ideas could reach Estonia. Since then the Estonian charismatic and Pentecostal movements have been in contact with the larger charismatic and Pentecostal world and are part of the global charismatic network.

It is difficult to estimate the number of people involved in the charismatic and Pentecostal Churches in Estonia. When looking at the data from the 2011 population census, and if we add together the 1,855 members of Pentecostal, Christian Episcopalian and Christian Fellowship Churches with 79 and 99 affiliates, 2,187 affiliates of Christian free churches and 36 revivalists, we may say that there are altogether 5,256 charismatics and Pentecostals in Estonia. However, there are charismatics also among 4,507 Baptists and there were also 1,899 undefined Christians who registered in the census.

In 2007 the Steve Hill Miracle Crusade, organized by the Estonian Christian Pentecostal Church brought together six thousand people over two nights (Kärmas 2007). The charismatic movement may well be the second largest Protestant tradition in Estonia just after Lutherans, especially if the varieties of spirituality which are represented by Estonian Baptism with influences from different charismatic and Pentecostal strands due to historical reasons are taken into account.

Ringo Ringvee is a historian of religion with the special interest in contemporary society. He holds the post of Professor extraordinarius in Comparative Religion at the Theological Institute of the Estonian Evangelical Church, and is also affiliated with the University of Tartu as a member of a research group for religious studies at the Centre of Excel-

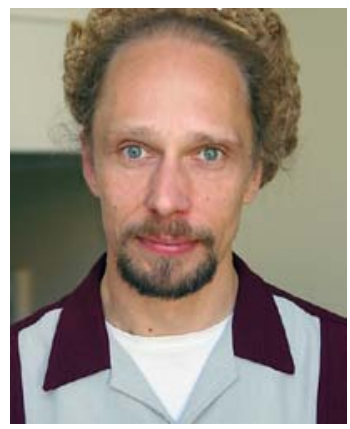
lence in Cultural Theory. He has published several articles on the relations between the state and religious associations in contemporary Estonia.

\section{References}

Alvarsson, Jan-Åke, 2011. 'The development of Pentecostalism in Scandinavian countries' in European Pentecostalism, ed. William K. Kay and Anne E. Dyer (Leiden, Boston, Brill), pp. 19-40

Anderson, Allan Heaton, 2014. An Introduction to Pentecostalism: Global Charismatic Christianity, 2nd edn (Cambridge University Press)

Aronson, Torbjorn, 2011. 'Continuity in charismata: Swedish Mission and the growth of neo-Pentecostal churches in Russia, Religion in Eastern Europe 31(1), pp. $33-40$

Betz, Ulrich, and Susanne Lohmeyer, nd. 'Stolpersteine Hamburg (Stumbling blocks of Hamburg): a "Jewish Christian” Israel Johannes Rubanovitsch, <http:// eja.pri.ee/history/Holocaust/Rubanovitsch_en.pdf $>$ (accessed 6.10.2014)

Busch, M., 1928. Ridala ärkamise ajalugu (Keila, Külvaja)

Eesmaa, Annely, 2012. 'Eesti Karismaatiline Osaduskirik' in Uued usulised ja vaimsed liikumised Eestis, ed. Lea Altnurme (Tartu Ülikooli Kirjastus), pp. 35-40

Hermaküla, Iir, 2007. 'Elu Sõna liikumine aastatel 1987-1988', Theological Seminary of the Estonian Methodist Church, unpublished diploma thesis

Housing and Population Census Database, 2011. <http:// pub.stat.ee/px-web.2001/I_Databas/Population_census/PHC2011/o1Demographic_and_ethno_cultural_ 
characteristics/o8Religious_affiliation/o8Religious_ affiliation.asp $>$ (accessed 6.10.2014)

Jakobs, Hubert, 2002. Harta 87, <http://harta.ee/harta-87/ harta-87-hubert-jakobs/> (accessed 6.10.2014)

Kärkkäinen, Veli-Matti, 2003. 'The Pentecostal movement in Finland', The Journal of the European Pentecostal Theological Association, 23, pp. 102-28

Kärmas, Mihkel, 2007. 'Tallinna megajutlus 500 miljonile vaatajale', Eesti Ekspress, 25.10.2007

Kärner, Jaanus, 2006. Letter to Hubert Jakobs, 27.5.2006, $<$ http://usumaailm.harta.ee/arhiiv.php?mida=loe\&tu up $=$ artikel\&id $=70>($ accessed 6.10.2014)

Kaups, Karl, 1935. 'Kojuhüütud ustavaid sulaseid' in 50 aastat apostlite radadel. Jooni baptisti koguduste eluarengust Eestis, ed. R. Kaups (Keila, E.B.K. Liidu Kirjastus), pp.100-44

Kiil, Evald, 1997. Meenutusi nelipühi ärkamisest Eestis (Tallinn, Logos)

Kõlar, Anu, 2012. Eks teie tea... Oleviste muusikaelust aastail 1950-2012 (Tallinn, Oleviste Kogudus)

Kraeuter, Tom, 2012. The Great Soviet Awakening (Hillsboro, MO, Training Resources)

Kroll, Allan, 2006. 'Effataa ärkamine', Theological Seminary of the Estonian Methodist Church, unpublished diploma thesis

Laar, Mart, Urmas Ott, and Sirje Endre, 1996. Teine Eesti. Eesti iseseisvuse taassünd 1986-1991 (Tallinn, SE \& JS)

Laks, Johannes, 1966. Evangeeliumi kristlaste vabakoguduse ajalooline ülevaade 1905-1930 (Toronto, Vabakoguduse Kirjastus)

Mozer, Pavel, and Oleg Bornovolokov, 2011. 'The development of Pentecostalism in Russia and the Ukraine' in European Pentecostalism, ed. William K. Kay and Anne E. Dyer (Leiden, Boston, Brill), pp. 261-94

Pilli, Toivo, 2007. Usu värvid ja varjundid. Eesti vabakoguduste ajaloost ja identiteedist (Tallinn, Allika)

-2008. Dance or Die: The Shaping of Estonian Baptist Identity under Communism (Milton Keynes, Paternoster)

-2009. 'Eesti EKB Koguduste Liidu ajaloost ja tänapäevast' in Osaduses kasvanud, ed. Üllas Linder and Toivo Pilli (Tallinn, Eesti EKB Koguduste Liit), pp. 9-19

Plaat, Jaanus, 2001. Usuliikumised, kirikud ja vabakogudused Lääne- ja Hiiumaal. Usuühenduste muutumisprotsessid 18. Sajandi keskpaigast kuni 20. Sajandi lõpuni (Tartu, Eesti Rahva Muuseum)

-2003. Saaremaa kirikud, usuliikumised ja prohvetid 18.-20. sajandil (Tartu, Eesti Rahva Muuseum)

Raadio 7 website. About Us, <http://www.raadio7.ee/ meist/> (accessed 6.10.2014)

Rahvastiku koostis ja korteriolud, 1935. Rahvastiku koostis ja korteriolud 1. III 1934 rahvaloenduse andmed. Vihk II (Tallinn, Riigi Statistika Keskbüroo)

Ringvee, Ringo, 2012a. 'Karismaatiline kristlus - Vineyard' in Uued usulised ja vaimsed liikumised Eestis, ed. Lea Altnurme (Tartu Ülikooli Kirjastus), pp. 47-9

-2012b. 'Karismaatiline Episkopaalkirik' in Uued usulised ja vaimsed liikumised Eestis, ed. Lea Altnurme (Tartu Ülikooli Kirjastus), pp. 36-9

Ritsbek, Heigo, 1996. 'The Mission of Methodism in Estonia', Boston University School of Theology, unpublished thesis

Rohtmets, Priit, 2009. 'Development of the membership' in History of Estonian Ecumenism, ed. Riho Altnurme (Tallinn, Estonian council of Churches; Tartu, The University of Tartu), pp. 273-309

Rohtmets, Priit, and Ringo Ringvee, 2013. 'Religious revival and the political activity of religious communities in Estonia during the process of liberation and the collapse of the Soviet Union 1985-1991', Religion, State and Society, 41(4), 355-93

Saard, Riho, 2010. Tallinn vaim. Peatükk XX sajandi Eesti karismaatilise liikumise aja- ja mõtteloost (Tallinn, Saard)

Schmidt, Wolfgang, 1935. Die Pfingstbewegung in Finnland (Helsinki, Kirchengeschichtliche Gesellschaft Finnlands)

Talonen, Jouko, 1988. Viron lestadiolaisuus 1886-1953 (Rovaniemi, Pohjois-Suomen historiallinen yhdistys)

Teraudkalns, Valdis, 2001. 'Pentecostalism in the Baltics: historical retrospection', The Journal of the European Pentecostal Theological Association, 21, pp. 91-108

Uuemõis, Haljand, 2010. Mäletamised ja vaatenurgad (Tallinn, Uuemõis)

Vööbus, Arthur, 1974. Studies in the History of the Estonian People, vol. 3, Papers of the Estonian Theological Society in Exile, 26 (Stockholm, ETSE)

Village of Hope webpage. <http://www.lootusekula.ee/ index.php?page $=10>($ accessed 6.10.2014)

Wardin, Albert W. Jr, 2013. On the Edge: Baptists and Other Free Church Evangelicals in Tsarist Russia 1855-1917 (Eugene, OR, Wipf \& Stock) 